\title{
African Vegetables (Clerodendrum volubile Leaf and Irvingia gabonensis Seed Extracts) Effectively Mitigate Trastuzumab- Induced Cardiotoxicity in Wistar Rats
}

\author{
Olufunke Olorundare, ${ }^{1}$ Adejuwon Adeneye $\mathbb{D}^{2},{ }^{2}$ Akinyele Akinsola, ${ }^{1}$ Sunday Soyemi, ${ }^{3}$ \\ Alban Mgbehoma, ${ }^{3}$ Ikechukwu Okoye, ${ }^{4}$ James M. Ntambi, $^{5}$ and Hasan Mukhtar ${ }^{6}{ }^{6}$ \\ ${ }^{1}$ Department of Pharmacology and Therapeutics, Faculty of Basic Medical Sciences, College of Health Sciences, University of Ilorin, \\ Ilorin, Kwara State, Nigeria \\ ${ }^{2}$ Department of Pharmacology, Therapeutics and Toxicology, Faculty of Basic Clinical Sciences, Lagos State University College \\ of Medicine, 1-5 Oba Akinjobi Way, G.R.A., Ikeja, Lagos State, Nigeria \\ ${ }^{3}$ Department of Pathology and Forensic Medicine, Faculty of Basic Clinical Sciences, Lagos State University College of Medicine, 1 - \\ 5 Oba Akinjobi Way, G.R.A., Ikeja, Lagos State, Nigeria \\ ${ }^{4}$ Department of Oral Pathology and Medicine, Faculty of Dentistry, Lagos State University College of Medicine, 1-5 Oba \\ Akinjobi Way, G.R.A., Ikeja, Lagos State, Nigeria \\ ${ }^{5}$ Department of Nutritional Sciences, College of Agricultural and Life Sciences, University of Wisconsin, Madison, 433 Babcock Drive, \\ Madison, WI 53706-1544, USA \\ ${ }^{6}$ Department of Dermatology, University of Wisconsin, Madison, Medical Science Center, 1300 University Avenue, Madison, \\ WI 53706, USA
}

Correspondence should be addressed to Adejuwon Adeneye; adeneye2001@yahoo.com

Received 29 May 2020; Revised 14 September 2020; Accepted 22 September 2020; Published 15 October 2020

Academic Editor: Demetrios Kouretas

Copyright (c) 2020 Olufunke Olorundare et al. This is an open access article distributed under the Creative Commons Attribution License, which permits unrestricted use, distribution, and reproduction in any medium, provided the original work is properly cited.

\begin{abstract}
Trastuzumab (TZM) is a humanized monoclonal antibody that has been approved for the clinical management of HER2-positive metastatic breast and gastric cancers but its use is limited by its cumulative dose and off-target cardiotoxicity. Unfortunately, till date, there is no approved antidote to this off-target toxicity. Therefore, an acute study was designed at investigating the protective potential and mechanism(s) of CVE and IGE in TZM-induced cardiotoxicity utilizing cardiac enzyme and oxidative stress markers and histopathological endpoints. $400 \mathrm{mg} / \mathrm{kg} /$ day $C V E$ and IGE dissolved in 5\% DMSO in sterile water were investigated in Wistar rats injected with $2.25 \mathrm{mg} / \mathrm{kg} /$ day/i.p. route of TZM for 7 days, using serum $c T n I$ and LDH, complete lipid profile, cardiac tissue oxidative stress markers assays, and histopathological examination of TZM-intoxicated heart tissue. Results showed that $400 \mathrm{mg} / \mathrm{kg} / \mathrm{day} C V E$ and $I G E$ profoundly attenuated increases in the serum $c T n I$ and LDH levels but caused no significant alterations in the serum lipids and weight gain pattern in the treated rats. CVE and IGE profoundly attenuated alterations in the cardiac tissue oxidative stress markers' activities while improving TZM-associated cardiac histological lesions. These results suggest that CVE and IGE could be mediating its cardioprotection via antioxidant, free radical scavenging, and antithrombotic mechanisms, thus, highlighting the therapeutic potentials of CVE and IGE in the management of TZM-mediated cardiotoxicity.
\end{abstract}

\section{Introduction}

Trastuzumab, a humanized monoclonal antibody targeted against epidermal growth factor receptor 2 (HER2), was approved by the United States Food and Drug Administration (FDA) for the clinical management of HER2-positive breast cancers either as an adjuvant or neoadjuvant, and metastatic breast and gastric carcinomas and metastatic 
gastric cancer [1]. In mediating its cytotoxic action, trastuzumab is known to bind to the domain IV of the extracellular domain of HER2 and triggers cascade tumorsuppressive actions including the activation of antibodydependent cell-mediated cytotoxicity, inhibition of HER2 extracellular domain cleavage, disruption of HER2 receptor homo- and heterodimerization extracellular segment of HER2 and consequently resulting in the inhibition of HER2-mediated malignant transformation $[1,2]$. Trastuzumab use as a key treatment therapy for advanced HER2positive breast carcinoma has also been reported to have yielded unequivocal improvements in the clinical treatment outcome of this disease [3]. Clinically, trastuzumab is either used alone or in combination with other cytotoxic agents especially with the anthracycline doxorubicin usually in a pegylated form although it is reported to be most effective in its combination form [4] since DOX enters its target cells by simple diffusion, intercalates into DNA, and inhibits topoisomerase II to hinder and completely stall DNA replication [5]. However, wide-scale clinical use of trastuzumabbased therapies has been significantly limited by its adverse cardiac dysfunctions and dilated cardiomyopathy-related congestive heart failures, which have been reported to occur in up to $27 \%$ of HER2-positive metastatic breast cancer patients on its combination therapy with doxorubicin [2]. Trastuzumab has been reported to dysregulate HER2 signaling pathways and suppress autophagy by activating autophagy-inhibitory Erk/mTOR/Ulk 1 signaling cascade in cardiomyocytes and overtly resulting in the massive mitochondrial and toxic reactive oxygen species (ROS) accumulation in human cardiomyocytes [6, 7]. As a clinical strategy of preventing the development of trastuzumabinduced cardiotoxicity, $\mathrm{Wu}$ et al. [8] recently investigated and reported the clinical efficacy and attenuation of trastuzumab-induced cardiac dysfunction in HER2positive breast cancer patients using fixed $440 \mathrm{mg}$ dose monthly administration of trastuzumab. Unfortunately, till date, there are no approved effective therapeutic agent(s) available that could prevent the development of this unwanted/adverse effect of trastuzumab without comprising its efficacy.

Clerodendrum volubile P. Beauv (known as White butterfly in English language) is a climbing and edible West African vegetable, belonging to the Verbenaceae family [9] but was recently reclassified to as belonging to the Labiatae family [10]. In the Niger-Delta region of Nigeria where the plant is predominantly cultivated for consumption wholly as green leafy vegetable or as food condiment to improve soup taste, it is used for the local management of gouty arthritis, rheumatism, dropsy, swellings/edema, and ulcers $[9,11]$. Phytochemically, Clerodendrum volubile leaf extracts have been reported to contain secondary metabolites such as alkaloids, flavonoids, saponins, anthraquinone, and cardiac glycoside [12]. The phenolic-rich solvent fractions of the plant extract have been reported to elicit antihyperglycemic activity through $\alpha$-amylase, $\alpha$-glucosidase, and improvement in the glucose tolerance while its antihypertensive activity was mediated via angiotensin I converting enzyme inhibition $[9,10]$. Similarly, the antioxidative, immunomodulatory, anti-inflammatory, and cytotoxic activities of the plant have also been reported [12-15]. Clerodendrum volubile is reported to be very rich in polyphenols (especially flavonoids) content which is conferred on its potent antioxidant potential $[9,16,17]$.

Irvingia gabonensis (Aubry-Lecomte ex O'Rorke) Bail belonging to the family, Irvingiaceae, is known as African Mango (in English). Its common English names include bread tree, African wild mango, wild mango, and bush mango [18, 19], while its local names in Nigeria include "Apon" and "Ogbono" (amongst the Yoruba, Southwest Nigeria and Igbo, Southeast Nigeria, respectively). Irvingia gabonensis is widely cultivated in West African countries including southwest and southeast Nigeria, southern Cameroon, Côte d'Ivoire, Ghana, Togo, and Benin, to produce its edible fruit whose seed is used in the preparation of local delicious viscous soup for swallowing yam and cassava puddings [20]. Fat extracted from its seeds is commonly known as dika fat and majorly consists of $\mathrm{C} 12$ and $\mathrm{C} 14$ fatty acids, alongside with smaller quantities of C10, C16 and C18, glycerides, and proteins [20]. Irvingia gabonensis seeds are also a good source of nutrients including a variety of vitamins and minerals such as sodium, calcium, magnesium, phosphorus, and iron. It is also a rich source of flavonoids (quercetin and kaempferol), ellagic acid, mono-, di-, and tri-O-methyl-ellagic acids, and their glycosides which are potent antioxidants [21, 22]. Phytochemical analysis of its seeds showed that it contains tannins, alkaloids, flavonoids, cardiac glycosides, steroids, carbohydrate, volatile oils, and terpenoids [23-25] and its proximate composition of moisture $1.4 \pm 0.11 \%$, ash $6.8 \pm$ $0.12 \%$, crude lipid $7.9 \pm 0.01 \%$, crude fibre $21.6 \pm 0.45 \%$, and crude protein $5.6 \pm 0.20 \%$ [25]. Similarly, proximate analysis of its soup shows that it contains 9\% protein, $70.42 \%$ fat, $4.61 \%$ fibre, $1.92 \%$ ash, and $11.91 \%$ carbohydrate [26]. Specific compounds already isolated from the seed extract of include: methyl 2- [2-formyl-5-(hydroxymethyl)$1 \mathrm{H}$-pyrrollyl]-propanoate, kaempferol-3-0- $\beta$-D-6" (p-coumaroyl) glucopyranoside and lupeol (3 $\beta$-lup-20(29)-en-3-ol with lupeol exhibiting the most abundant with the most significant antioxidant activities [27].

In the absence of any clinically approved chemotherapeutic or chemoprophylactic agents for the clinical management of trastuzumab-induced cardiovascular events, the current study was designed at investigating possible ameliorative potential of the ethanol extracts of Clerodendrum volubile leaves and Irvingia gabonensis seeds in trastuzumab-induced cardiotoxicity in Wistar rats intraperitoneally injected with $2.25 \mathrm{mg} / \mathrm{kg} /$ day of trastuzumab for 7 days. The effects of oral pretreatments with $400 \mathrm{mg} / \mathrm{kg} / \mathrm{day}$ of Clerodendrum volubile ethanol leaf extract as well as $400 \mathrm{mg} / \mathrm{kg} /$ day of Irvingia gabonensis ethanol seed extract were investigated in trastuzumab intoxicated rat hearts using cardiac enzyme biomarkers such as cardiac troponin I ( $c T n I)$ and cardiac lactate dehydrogenase (LDH), complete lipid profile, cardiovascular disease risk indices (atherogenic index (AI) and coronary artery disease risk index (CRI)), oxidative stress markers, as well as the histopathological studies of the trastuzumab-treated cardiac tissues as measuring endpoints for the study. 


\section{Materials and Methods}

2.1. Plant Materials. Stock of fresh mature whole plants of Clerodendrum volubile and fresh seeds of Irvingia gabonensis were purchased from Herbal Vendors in Isikan Market in Akure, Ondo State, Nigeria, in the month of February 2020. Samples of the Clerodendrum volubile plant obtained were subjected to botanical identification and referencing at the University of Ilorin (UNILORIN) Herbarium with a voucher specimen number: UIL/001/2019/1254 as previously reported by Akinsola (2019) [28]. Fresh leaves, inflorescence, and fruits of Irvingia gabonensis were equally processed for botanical identification and authentication and voucher specimen with reference number (UIL/001/2019/1364) was also deposited in UNILORIN Herbarium.

2.2. Extraction Process. Fresh leaves of Clerodendrum volubile were destalked from the whole plant, then gently but thoroughly rinsed under running tap water and completely airdried at the room temperature $\left(28-33^{\circ} \mathrm{C}\right)$ until the weight of the dried leaves was constant. The dried leaves were then pulverized using Milling Machine and kept in water- and airtight containers.

$1.50 \mathrm{~kg}$ of the pulverized leaves was completely macerated in 8 liters of absolute ethanol at room temperature for 5 days but intermittently shaken to ensure complete dissolution. Thereafter, the solution was first filtered with cotton wool and then $110 \mathrm{~mm}$ Whatman filter paper. The resultant filtrate was then concentrated in vacuo using a rotary evaporator (B' ${ }^{\cdot}$ CHI Rotavapor ${ }^{\circledR}$ Model R-215, Switzerland) with Vacuum Module V-801 EasyVac ${ }^{\circledR}$, Switzerland) set at a revolution of $70 \mathrm{rpm}$ and a temperature at $36^{\circ} \mathrm{C}$ before it was completely dried over a water bath preset at $40^{\circ} \mathrm{C}$. The jellylike, dark-colored residue left behind was weighed, stored in air- and water-proof container which was kept in a refrigerator at $4^{\circ} \mathrm{C}$. From this stock, fresh solutions were made whenever required.

$\%$ Yield was calculated as $=$ (weight of crude extract obtained $(g)$ /weight of starting pulverized dry leaf extracted $(g)) \times 100$.

The same procedure was performed with $1.5 \mathrm{~kg}$ of the pulverized, dried seeds of Irvingia gabonensis.

2.3. Experimental Animals. Young adult male Wistar Albino rats (aged 8-12 weeks old and body weight: 150-190 g) used in this study were obtained from the Animal House of the Lagos State University College of Medicine, Ikeja, Lagos State, Nigeria, after an ethical approval (UERC Approval number: UERC/ASN/2020/2072) was obtained from the University of Ilorin Ethical Review Committee for Postgraduate Research. The rats were handled in accordance with international principles guiding the Use and Handling of Experimental Animals [29]. The rats were maintained on standard rat feed (Ladokun Feeds, Ibadan, Oyo State, Nigeria) and potable water which were made available ad libitum. The rats were maintained at an ambient temperature between $28-30^{\circ} \mathrm{C}$, humidity of $55 \pm 5 \%$, and standard (natural) photoperiod of approximately 12/12 hours of alternating light and dark periodicity.
2.4. Measurement of Body Weight. The body weights of rats were taken on days 1 and 7 of the experiment and determined on a digital rodent weighing scale ( ${ }^{\circledR}$ Virgo Electronic Compact Scale, New Delhi, India). The obtained values were expressed in grams $(\mathrm{g})$.

\subsection{Induction of Trastuzumab- (TZM-) Induced} Cardiotoxicity and Other Drug Treatment of Rats. Prior to commencement of the experiment, rats were randomly allotted into 7 groups of 7 rats per group such that the weight difference between and within groups was not more than $\pm 20 \%$ of the average weight of the sample population of rats used for the study. However, the choice of the therapeutic dose range of $400 \mathrm{mg} / \mathrm{kg} / \mathrm{day}$ of $C V E$ and IGE was made based on the results of the preliminary studies conducted.

In this experimental repeated-dose model, Group I rats which served as untreated control were orally pretreated with $10 \mathrm{ml} / \mathrm{kg} /$ day of sterile water but equally treated with $1 \mathrm{ml} / \mathrm{kg} /$ day of sterile water and administered via intraperitoneally for 7 days. Group II and III rats were orally treated with $400 \mathrm{mg} / \mathrm{kg} /$ day of CVE and IGE dissolved in 5\% DMSO sterile water (CVE and IGE being only partly soluble in water and DMSO an organosulfur polar aprotic and inert solvent that readily dissolves both polar and nonpolar compounds) but treated with $1 \mathrm{ml} / \mathrm{kg} /$ day of sterile water and administered intraperitoneally for 7 days, respectively. Group IV rats were orally pretreated with $10 \mathrm{ml} / \mathrm{kg} /$ day of sterile water 3 hours before intraperitoneal injection of $2.25 \mathrm{mg} / \mathrm{kg} /$ day of TZM ( ${ }^{\circledR}$ CAMMab, Biocon Limited, Km 34 Tumkur Road, T-Bengur, Nelamangala Taluk, Bangalore-56 123, India) dissolved in accompanying sterile water for 7 days. Group V rats which served as the positive control group were equally pretreated with $20 \mathrm{mg} / \mathrm{kg} /$ day of Vitamin C 3 hours before treatment with $2.25 \mathrm{mg} / \mathrm{kg} /$ day of TZM dissolved in sterile water administered intraperitoneally for 7 days. Group VI and VII rats were orally pretreated with $400 \mathrm{mg} / \mathrm{kg} /$ day of $C V E$ and IGE 3 hours before treatment with $2.25 \mathrm{mg} / \mathrm{kg}$ of TZM dissolved in sterile water and administered intraperitoneally daily for 7 days (Table 1). The choice of vitamin C was made being a standard antioxidant agent, and its effect as positive control was compared with other treatment groups. The dose of TZM adopted was as described by Poon et al. [30] and Riccio et al. [31].

2.6. Blood Sample Collection. On the $7^{\text {th }}$ day which was the last day of the experiment, the rats were weighed and later fasted overnight but drinking water was made available ad libitum. On the $8^{\text {th }}$ day, fasted rats were sacrificed and whole blood samples were collected directly from the heart under inhaled diethyl ether anesthesia. Blood samples were carefully collected with a fine $21 \mathrm{G}$ Needle and $5 \mathrm{ml}$ Syringe (Hangzhou Longde Medical Products Co. Ltd., Hangzhou, China) without causing damage to the heart tissues. The rat heart, liver, and kidneys were identified, harvested en bloc, and weighed on a digital weighing scale.

2.7. Biochemical Assays. Blood samples obtained directly from the heart chamber were allowed to clot and then centrifuged at $5000 \mathrm{rpm}$ to separate clear sera from the clotted 
TABLE 1: Group treatment of rats.

\begin{tabular}{|c|c|}
\hline Groups & Treatments \\
\hline Group I & $\begin{array}{l}10 \mathrm{ml} / \mathrm{kg} / \text { day of sterile water p.o. for } 7 \text { days }+1 \mathrm{ml} / \mathrm{kg} / \\
\text { day of sterile water given i.p. for } 7 \text { days }\end{array}$ \\
\hline Group II & $\begin{array}{c}400 \mathrm{mg} / \mathrm{kg} / \text { day of CVE dissolved in } 5 \% \text { DMSO-sterile } \\
\text { water p.o. for } 7 \text { days }+1 \mathrm{ml} / \mathrm{kg} / \text { day of sterile water } \\
\text { given i.p. for } 7 \text { days }\end{array}$ \\
\hline Group III & $\begin{array}{c}400 \mathrm{mg} / \mathrm{kg} / \text { day of } I G E \text { dissolved in } 5 \% \text { DMSO-sterile } \\
\text { water p.o. for } 7 \text { days }+1 \mathrm{ml} / \mathrm{kg} / \text { day of sterile water } \\
\text { given i.p. for } 7 \text { days }\end{array}$ \\
\hline Group IV & $\begin{array}{c}10 \mathrm{ml} / \mathrm{kg} / \text { day of sterile water } p . o \text {. for } 7 \text { days }+2.25 \mathrm{mg} / \\
\mathrm{kg} / \text { day of TZM dissolved in sterile water given i.p. } \\
\text { for } 7 \text { days }\end{array}$ \\
\hline Group V & $\begin{array}{c}20 \mathrm{mg} / \mathrm{kg} / \text { day of vitamin } \mathrm{C} \text { dissolved in sterile water } \\
\text { p.o. for } 7 \text { days }+2.25 \mathrm{mg} / \mathrm{kg} / \text { day of } \\
\text { TZM dissolved in sterile water given i.p. for } 7 \text { days }\end{array}$ \\
\hline Group VI & $\begin{array}{c}400 \mathrm{mg} / \mathrm{kg} / \text { day of CVE dissolved in 5\% DMSO-sterile } \\
\text { water p.o. for } 7 \text { days }+2.25 \mathrm{mg} / \mathrm{kg} / \text { day of } T Z M \\
\text { dissolved in sterile water given i.p. for } 7 \text { days }\end{array}$ \\
\hline Group VII & $\begin{array}{c}400 \mathrm{mg} / \mathrm{kg} / \text { day of } I G E \text { dissolved in } 5 \% \text { DMSO-sterile } \\
\text { water p.o. for } 7 \text { days }+2.25 \mathrm{mg} / \mathrm{kg} / \text { day of TZM } \\
\text { dissolved in sterile water given i.p. for } 7 \text { days }\end{array}$ \\
\hline
\end{tabular}

blood samples. The clear samples were obtained for assays of the following biochemical parameters: serum cardiac tropo$\operatorname{nin}$ I, LDH, TG, TC, and cholesterol fractions (HDL-c, LDL-c, and VLDL-c). Serum lipids were assayed using methods of Tietz [32] while serum $c T n I$ and LDH were estimated standard bioassay procedures.

2.8. Calculation of AI and CRI. AI was calculated as LDL $\mathrm{c}(\mathrm{mg} / \mathrm{dl}) \div \mathrm{HDL}-\mathrm{c}(\mathrm{mg} / \mathrm{dl})$ [33] while CRI was calculated as $\mathrm{TC}(\mathrm{mg} / \mathrm{dl}) \div \mathrm{HDL}-\mathrm{c}(\mathrm{mg} / \mathrm{dl})$ [34]

2.9. Determination of Antioxidant Activities in the Rat Cardiac Tissues. After the rats were sacrificed humanely under inhaled diethyl ether, the heart was harvested en bloc. The heart was gently and carefully divided into two halves (each consisting of the atrium and ventricle) using a new surgical blade. The left half of the heart was briskly rinsed in icecold $1.15 \% \mathrm{KCl}$ solution in order to preserve the oxidative enzyme activities of the heart before being placed in a clean sample bottle which itself was in an ice-pack filled cooler. This is to prevent the breakdown of the oxidative stress enzymes in these organs.

2.9.1. Determination of SOD Activities in the Heart Tissues. Superoxide dismutase activity was determined by its ability to inhibit the autooxidation of epinephrine by the increase in absorbance at $480 \mathrm{~nm}$ as described by Paoletti et al. [35]. Enzyme activity was calculated by measuring the change in absorbance at $480 \mathrm{~nm}$ for 5 minutes.

2.9.2. Determination of CAT Activities in the Heart Tissues. Tissue CAT activities were determined by the method described by Hadwan [36]. The specific activity of CAT was expressed as $\mathrm{U} / \mathrm{ml}$.
2.9.3. Determination of GSH, GPx, and GST Activities in the Heart Tissue. The reduced glutathione (GSH) content in the heart tissue was estimated according to the method described by Rahman et al. [37]. To the homogenate, $10 \%$ TCA was added and centrifuged. One millilitre of the supernatant was treated with $0.5 \mathrm{ml}$ of Elman's reagent $(19.8 \mathrm{mg}$ of 5,5 -dithiobisnitro benzoic acid (DTNB) in $100 \mathrm{ml}$ of $0.1 \%$ sodium nitrate) and $-3.0 \mathrm{ml}$ of phosphate buffer $(0.2 \mathrm{M}$, $\mathrm{pH}$ 8.0). The absorbance was read at $412 \mathrm{~nm}$. Similarly, GPx and GST activities were determined using the method of Faraji et al. [38] and Vontas et al. [39].

2.9.4. Determination of MDA Activities in the Heart Tissues. The method of Buege and Aust [40] was adopted in determining MDA activities in the cardiac tissue. One millilitre of supernatant was added to $2 \mathrm{ml}$ of (1:1:1 ratio) TCATBA- $\mathrm{HCl}$ reagent (thiobarbituric acid $0.37 \%, 0.24 \mathrm{~N} \mathrm{HCl}$, and 15\% TCA) tricarboxylic acid, thiobarbituric acid, reagent boiled at $100^{\circ} \mathrm{C}$ for 15 minutes, and allowed to cool. Flocculent material was removed by centrifuging at $3000 \mathrm{rpm}$ for ten minutes. The supernatant was removed, and the absorbance was read at $532 \mathrm{~nm}$ against a blank. MDA was calculated using the molar extinction for MDA-TBA-complex of $1.56 \times 10^{5} \mathrm{~m}^{-1} \mathrm{~cm}^{-1}$.

2.9.5. Histopathological Studies of the Heart. Using the remaining equally divided harvested heart, the right halves of the seven randomly selected rats from each treatment and control groups were subjected to histopathological examinations, the right ventricle being the most susceptible to doxorubicin toxicity of the heart chambers. After rinsing in normal saline, the dissected right half of was preserved in $10 \%$ formo-saline before it was completely dehydrated in absolute (100\%) ethanol. It was then embedded in routine paraffin blocks. From the embedded paraffin blocks, $4-5 \mu \mathrm{m}$ thick sections of the tissue was prepared and stained with hematoxylin-eosin stain. These were examined under a photomicroscope (Model N-400ME, CEL-TECH Diagnostics, Hamburg, Germany) connected with a host computer. Sections were illuminated with white light from a $12 \mathrm{~V}$ halogen lamp $(100 \mathrm{~W})$ after filtering with a $520 \mathrm{~nm}$ monochromatic filter. The slides were examined for associated histopathological lesions [41].

2.10. Statistical Analysis. Data were presented as mean \pm S.D. and mean \pm S.E.M. of seven observations for the body weight and biochemical parameters, respectively. Statistical analysis was done using a two-way analysis of variance followed by post hoc test, Student-Newman-Keuls test on GraphPad Prism Version 5. Statistical significance was considered at $p$ $<0.05, p<0.01$, and $p<0.001$.

\section{Results}

3.1. \% Yield. Complete extraction of the pulverized dry leaves Clerodendrum volubile in absolute ethanol was calculated to be $8.39 \%$. The resultant residue was a dark color, sticky and jelly-like, sweet-smelling (bland) residue which was not completely soluble in water but completely soluble in methanol and ethanol. Similarly, complete extraction of Irvingia 
gabonensis ethanol seed extract in absolute ethanol resulted in a yield of $58 \%$, which was a dark brown oily and aromatic residue that was only soluble in methanol and ethanol.

3.2. Effect of CVE and IGE on the Average Body Weight of TZM-Treated Rats. Table 2 shows the effect of repeated daily intraperitoneal injection with $2.25 \mathrm{mg} / \mathrm{kg}$ of $T Z M$ and oral pretreatments with $20 \mathrm{mg} / \mathrm{kg} /$ day of vit. C and $400 \mathrm{mg} / \mathrm{kg} /$ day of $C V E$ and $I G E$, respectively, on the average body weight on days 1 and 7 , percentage weight change $(\% \Delta w t$.$) , and relative heart weight of treated rats. Repeated$ intraperitoneal TZM injection did not significantly alter $(p>0.05)$ the weight gain pattern and relative heart weight in the TZM only treated (Group IV) rats when compared to untreated control (normal) rats (Group II) as well as CVE(Group VI) and IGE- (Group VII) pretreated rats (Table 2). Similarly, vit. C pretreatment did not significantly alter the weight gain pattern and relative heart weight in the TZMtreated rats (Table 2).

3.3. Effect of CVE and IGE on Cardiac Marker Enzymes (LDH and $c T n I)$ of TZM-Treated Rats. Repeated daily intraperitoneal TZM injection for 7 days resulted in significant increases $(p<0.0001)$ in the serum LDH and $c T n I$ levels when compared to that of untreated negative (control) (Group I) values (Table 3). However, $400 \mathrm{mg} / \mathrm{kg} /$ day of CVE and IGE oral pretreatments significantly attenuated $(p<0.0001)$ increases in the serum LDH and $c T n I$ levels (Table 3). Similarly, $20 \mathrm{mg} / \mathrm{kg} /$ day of vit. C pretreatment also significantly $(p<0.001$ and $p<0.0001)$ attenuated increases in the serum LDH and $c$ TnI though at a lower level of statistical significance when compared to either CVE or IGE (Table 3).

3.4. Effect of CVE and IGE on the Serum Lipids (TG, TC, $H D L-c, L D L-c$, and VLDL-c) Level of TZM-Treated Rats. Repeated TZM intraperitoneal injections did not cause significant $(p>0.05)$ alterations in the serum lipids measured when compared to the untreated control (Group I) values (Table 4). However, repeated daily oral pretreatments with $400 \mathrm{mg} / \mathrm{kg} /$ day of $C V E$ and $I G E$ resulted in insignificant reductions in the serum levels of TG, TC, HDL-c, LDL-c, and VLDL-c when compared to TZM only-treated rats (Table 4). Similarly, vit. C did not cause significant $(p>0.05)$ alterations in the serum TG, TC, LDL-c, and VLDL-c levels when compared to TZM only-treated rats (Table 4).

3.5. Effect of CVE and IGE on the Atherogenic Index (AI) and Coronary Artery Disease Index (CRI) of TZM-Treated Rats. Repeated intraperitoneal injections with $2.25 \mathrm{mg} / \mathrm{kg} /$ day of $T Z M$ to treated rats resulted in an insignificant $(p>0.05)$ increase in the AI and CRI values when compared to the untreated control (Group I), CVE only treated (Group II), and IGE only treated (Group III) values (Table 5). Oral pretreatments with $400 \mathrm{mg} / \mathrm{kg} /$ day of $C V E$ and $I G E$, however, resulted in insignificant $(p>0.05)$ reductions in the AI and CRI values when compared to TZM only-treated rats (Table 5). Similar insignificant reductions $(p>0.05)$ in the $\mathrm{AI}$ and CRI values were caused by $20 \mathrm{mg} / \mathrm{kg} /$ day of vit. C oral pretreatment (Table 5).
TABLE 2: Effect of repeated oral pretreatments with $400 \mathrm{mg} / \mathrm{kg} / \mathrm{day}$ of CVE and IGE on the average body weights on days 1 and 7, percentage change in weight $(\% \Delta$ wt.) and relative heart weight (RHW) of TZM-treated rats.

\begin{tabular}{lcccc}
\hline Group & Day 1 bwt. (g) & Day 7 bwt. (g) & $\% \Delta$ wt. & RHW \\
\hline I & $175.8 \pm 25.2$ & $183.9 \pm 20.5$ & $05.1 \pm 04.9$ & $0.25 \pm 0.01$ \\
II & $178.2 \pm 27.9$ & $189.9 \pm 34.4$ & $06.2 \pm 05.1$ & $0.30 \pm 0.02$ \\
III & $183.4 \pm 37.7$ & $190.0 \pm 39.9$ & $03.5 \pm 02.9$ & $0.36 \pm 0.04$ \\
IV & $177.1 \pm 20.4$ & $188.5 \pm 23.6$ & $06.4 \pm 02.6$ & $0.37 \pm 0.01$ \\
V & $176.2 \pm 20.5$ & $185.0 \pm 23.5$ & $06.0 \pm 05.4$ & $0.38 \pm 0.02$ \\
VI & $171.5 \pm 17.7$ & $178.4 \pm 17.2$ & $04.2 \pm 04.1$ & $0.34 \pm 0.02$ \\
VII & $171.5 \pm 21.4$ & $180.7 \pm 22.9$ & $04.0 \pm 04.3$ & $0.40 \pm 0.03$ \\
\hline
\end{tabular}

TABLE 3: Effect of $400 \mathrm{mg} / \mathrm{kg} /$ day of $C V E$ and $I G E$ on serum LDH and $c T n I$ in $T Z M$-intoxicated rats.

\begin{tabular}{lcc}
\hline Treatment groups & LDH (U/L) & $c T n I(\mathrm{ng} / \mathrm{ml})$ \\
\hline I & $2826 \pm 637.1$ & $04.46 \pm 01.04$ \\
II & $3733 \pm 365.0$ & $05.05 \pm 01.38$ \\
III & $3634 \pm 318.8$ & $05.23 \pm 01.26$ \\
IV & $7200 \pm 371.7^{\mathrm{c}+}$ & $83.86 \pm 13.04^{\mathrm{c}+}$ \\
V & $2813 \pm 344.4^{\mathrm{c}-}$ & $11.06 \pm 02.50^{\mathrm{b}-}$ \\
VI & $3483 \pm 310.9^{\mathrm{c}-}$ & $06.35 \pm 02.05^{\mathrm{c}-}$ \\
VII & $3104 \pm 405.0^{\mathrm{c}-}$ & $04.45 \pm 02.73^{\mathrm{c}-}$ \\
\hline
\end{tabular}

${ }^{\mathrm{c}+}$ represents a significant increase at $p<0.0001$ when compared to Groups IIII values while ${ }^{\mathrm{b}-}$ and ${ }^{\mathrm{c}-}$ represent significant decreases at $p<0.001$ and $p$ $<0.0001$, respectively, when compared to untreated positive (TZM onlytreated only) control values, respectively.

3.6. Effect of CVE and IGE on the Cardiac Tissue Oxidative Stress Markers (GSH, GST, GPx, SOD, CAT, and MDA) of TZM-Treated Rats. Repeated TZM intraperitoneal injection to treated rats resulted in significant attenuation $(p<0.05$ and $p<0.0001)$ in SOD, CAT, GST activities, and GSH levels while there were significant increases $(p<0.0001)$ in the GPx and MDA activities (Table 6). However, repeated oral treatments with $400 \mathrm{mg} / \mathrm{kg} /$ day of $C V E$ and $I G E$ significantly $(p<0.001$ and $p<0.0001)$ attenuated the alterations in the activities of these oxidative stress markers in the cardiac tissue restoring their activities to normal as recorded for Groups I-III values. These values were also comparable to those of vit. C-treated group (Table 6).

3.7. Histological Effect of CVE and IGE on TZM-Treated Heart. Repeated intraperitoneal injections of rats with $2.25 \mathrm{mg} / \mathrm{kg} /$ day of TZM for 7 days resulted in marked vascular congestion, intraparenchymal hemorrhage, and coronary artery microthrombi formation with the preservation of the cardiac myocyte cytoarchitecture (Figure 1). This is in sharp contrast with normal coronary artery and cardiomyocyte architecture recorded for Groups I-III cardiac muscle that were orally treated with $10 \mathrm{ml} / \mathrm{kg} /$ day of sterile water, $400 \mathrm{mg} / \mathrm{kg} /$ day of $C V E$, and $400 \mathrm{mg} / \mathrm{kg} /$ day of IGE only, respectively, with no remarkable histological changes in the 
TABLE 4: Effect of $400 \mathrm{mg} / \mathrm{kg} /$ day of $C V E$ and $I G E$ on serum lipid profile of TZM-treated rats.

\begin{tabular}{lccccc}
\hline Groups & TG $(\mathrm{mmol} / \mathrm{l})$ & TC $(\mathrm{mmol} / \mathrm{l})$ & $\begin{array}{c}\text { Serum lipids } \\
\text { HDL-c }(\mathrm{mmol} / \mathrm{l})\end{array}$ & LDL-c $(\mathrm{mmol} / \mathrm{l})$ & VLDC-c $(\mathrm{mmol} / \mathrm{l})$ \\
\hline I & $1.00 \pm 0.11$ & $1.37 \pm 0.11$ & $0.40 \pm 0.03$ & $0.51 \pm 0.10$ & $0.45 \pm 0.05$ \\
II & $0.79 \pm 0.06$ & $1.41 \pm 0.13$ & $0.41 \pm 0.04$ & $0.64 \pm 0.08$ & $0.36 \pm 0.04$ \\
III & $0.79 \pm 0.09$ & $1.47 \pm 0.12$ & $0.44 \pm 0.04$ & $0.67 \pm 0.09$ & $0.36 \pm 0.04$ \\
IV & $0.96 \pm 0.05$ & $1.53 \pm 0.09$ & $0.44 \pm 0.02$ & $0.66 \pm 0.09$ & $0.43 \pm 0.02$ \\
V & $0.94 \pm 0.10$ & $1.51 \pm 0.10$ & $0.44 \pm 0.02$ & $0.64 \pm 0.07$ & $0.43 \pm 0.04$ \\
VI & $0.86 \pm 0.09$ & $1.40 \pm 0.13$ & $0.40 \pm 0.03$ & $0.62 \pm 0.07$ & $0.39 \pm 0.04$ \\
VII & $0.80 \pm 0.06$ & $1.45 \pm 0.08$ & $0.42 \pm 0.03$ & $0.67 \pm 0.04$ & $0.36 \pm 0.03$ \\
\hline
\end{tabular}

TABle 5: Effect of $400 \mathrm{mg} / \mathrm{kg} /$ day of $C V E$ and IGE on atherogenic index (AI) and coronary artery disease index (CRI) in TZMintoxicated rats.

\begin{tabular}{lcc}
\hline Treatment groups & AI & CRI \\
\hline I & $01.19 \pm 0.17$ & $03.39 \pm 0.08$ \\
II & $01.53 \pm 0.13$ & $03.45 \pm 0.11$ \\
III & $01.34 \pm 0.22$ & $03.39 \pm 0.04$ \\
IV & $01.65 \pm 0.16$ & $03.52 \pm 0.16$ \\
V & $01.18 \pm 0.06$ & $03.42 \pm 0.10$ \\
VI & $01.42 \pm 0.10$ & $03.50 \pm 0.09$ \\
VII & $01.59 \pm 0.09$ & $03.45 \pm 0.07$ \\
\hline
\end{tabular}

treated heart muscles (Figures 2-4). However, repeated oral pretreatments with $20 \mathrm{mg} / \mathrm{kg} /$ day of vit. C (standard antioxidant drug), $400 \mathrm{mg} / \mathrm{kg} /$ day of $C V E$, and $400 \mathrm{mg} / \mathrm{kg} /$ day of IGE markedly improved TZM-induced coronary artery histopathological alterations (Figures 5-7) with coronary artery recanalization recorded in IGE pretreated, TZM-treated (Group VII) rats (Figure 7).

\section{Discussion}

Trastuzumab either used alone or in combination with other agents from other classes of cytotoxic agents has remained a cornerstone and key strategy in the clinical management of patients with metastatic breast carcinoma overexpressing the HER2 protein $[42,43]$. Despite its wide application in this regard, its clinical use has been limited by its cumulative dose-limiting but reversible cardiotoxicity which manifests as a life-threatening dilated cardiomyopathy and congestive cardiac failure $[43,44]$. Unfortunately, till date, there are no approved effective chemotherapeutic/chemoprophylactic options available in its amelioration despite efforts being directed towards developing an effective therapeutic alternative, one of which is the antianginal agent, ranolazine, which has been reported to blunt trastuzumab cardiotoxicity mediated via redox-mediated mechanisms [31]. However, ranolazine's clinical use is known to be limited by its serious side effects such as bradycardia, syncope attacks, hematuria, acute renal failure, and its predilection to liver cirrhosis $[45,46]$. Therefore, this study investigated the ameliorative potential of CVE and IGE in TZM-related cardiotoxicity in experimental rats. In doing this, experimental TZM cardiotoxicity was reliably induced in the treated rats following repeated daily intraperitoneal injection of $2.25 \mathrm{mg} / \mathrm{kg}$ of TZM for 7 days as evidenced by profound elevations in the serum cardiac markers ( $c$ TnI and LDH), alterations in the serum lipids profile and cardiovascular disease risk indices, and marked alteration in the oxidative stress markers. All of these biochemical changes were corroborated by remarkable histological lesions such as vascular congestion, intraparenchymal hemorrhage, coronary artery endothelial thickening, and thrombi formation. $c T n I$ and $\mathrm{LDH}$ are considered reliable markers of cardiotoxicity and are as such used in monitoring druginduced-cardiotoxicities including TZM [47-52]. The fact that the serum levels of $c T n$ I and LDH were significantly elevated following repeated administration for 7 days is a strong indication that TZM-induced cardiac damage was reliably established and in consonance with reports of other studies $[49,51,53]$. However, repeated oral pretreatments with vitamin C, CVE, and IGE profoundly attenuated elevations in serum levels of these cardiac markers, thus, indicating the potential therapeutic role of these agents in mitigating the deleterious effects of TZM on the integrity cardiac myocytes.

Another significant finding of this study is the effect of TZM treatment on the circulating lipids levels. Prolonged TZM treatment was also being documented to be associated with dyslipidemia which is characterized by significant increases in the serum triglycerides, very low-density lipoprotein cholesterol (VLDL-c), and low-density lipoprotein cholesterol (LDL-c) [54, 55]. The findings of our study are in agreement with this assertion although TZM treatment for 7 days in our study was associated with slight improvements in the circulating lipids levels as well as the cardiovascular disease risk indices. The variance between our result of study and other studies could have resulted from the short duration of TZM treatment. This remains a hypothesis until validated by similar studies of longer duration. In the same vein, neither TZM treatment nor extracts pretreatment treatment causes any significant changes in the weight gain pattern of the treated rats. Again, it is possible that the short duration of the studies could be responsible for this.

TZM like other anticancer agents such as cisplatin has been reported to cause "acute coronary syndrome" which 
TABLe 6: Antioxidant activities of $400 \mathrm{mg} / \mathrm{kg} /$ day of CVE and IGE in TZM-intoxicated rat cardiac tissue.

\begin{tabular}{|c|c|c|c|c|c|c|}
\hline \multirow{2}{*}{ Groups } & \multicolumn{6}{|c|}{ Antioxidant parameters } \\
\hline & GSH & GST & GPx & SOD & CAT & MDA \\
\hline $\bar{I}$ & $26.8 \pm 3.0$ & $31.7 \pm 1.1$ & $28.5 \pm 2.8$ & $08.4 \pm 0.6$ & $44.5 \pm 1.2$ & $0.4 \pm 0.1$ \\
\hline II & $35.0 \pm 3.6$ & $29.3 \pm 0.9$ & $32.5 \pm 3.3$ & $07.7 \pm 0.5$ & $42.0 \pm 6.8$ & $0.5 \pm 0.3$ \\
\hline III & $33.5 \pm 4.5$ & $22.9 \pm 1.7$ & $24.8 \pm 1.8$ & $06.2 \pm 0.9$ & $33.4 \pm 7.2$ & $0.5 \pm 0.1$ \\
\hline IV & $16.7 \pm 2.1^{c-}$ & $19.8 \pm 2.2^{c-}$ & $46.9 \pm 2.0^{\mathrm{ft}}$ & $03.6 \pm 0.2^{c-}$ & $17.7 \pm 2.4^{c^{-}}$ & $0.8 \pm 0.1^{\mathrm{f}+}$ \\
\hline $\mathrm{V}$ & $29.5 \pm 3.3^{\mathrm{b}+}$ & $24.7 \pm 0.6^{\mathrm{b}+}$ & $19.9 \pm 1.1^{\mathrm{f}-}$ & $06.5 \pm 0.7^{\mathrm{c}+}$ & $26.0 \pm 2.6^{\mathrm{b}+}$ & $0.5 \pm 0.1^{\mathrm{f}-}$ \\
\hline VI & $28.3 \pm 1.6^{\mathrm{b}+}$ & $25.0 \pm 0.5^{\mathrm{b}+}$ & $19.6 \pm 1.8^{\mathrm{f}-}$ & $08.1 \pm 0.6^{\mathrm{c}+}$ & $26.9 \pm 1.2^{\mathrm{b}+}$ & $0.4 \pm 0.1^{\mathrm{f}-}$ \\
\hline VII & $34.8 \pm 2.7^{\mathrm{c}+}$ & $26.4 \pm 0.5^{\mathrm{c}+}$ & $16.7 \pm 2.1^{\mathrm{f}-}$ & $07.6 \pm 0.7^{\mathrm{c}+}$ & $30.2 \pm 2.6^{\mathrm{ct}}$ & $0.5 \pm 0.1^{\mathrm{f}-}$ \\
\hline
\end{tabular}

${ }^{c-}$ represents a significant decrease at $p<0.0001$ when compared to Groups I-III (controls) values while ${ }^{\mathrm{f}+}$ represents a significant increases at $p<0.0001$ when compared to Groups I-III values; ${ }^{\mathrm{b}+}$ and ${ }^{\mathrm{c}+}$ represent significant increases at $p<0.05$ and $p<0.0001$, respectively, when compared to Groups IV values while ${ }^{\mathrm{f}-}$ represents a significant decrease at $p<0.0001$ when compared to untreated positive control (TZM treated only, Group IV).

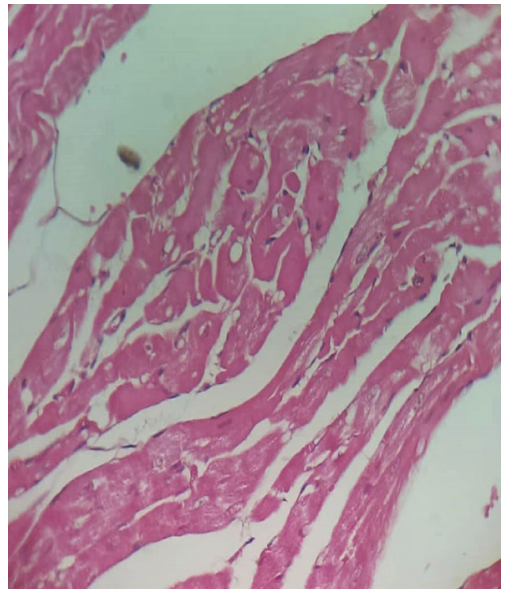

Figure 1: A cross-sectional representative of TZM intoxicated rat heart pretreated with $10 \mathrm{ml} / \mathrm{kg} /$ day of sterile water showing severe vascular congestion and intraparenchymal hemorrhage as well as coronary arterial wall thickening with endothelial microthrombi formation indicative of coronary arteriosclerosis (x400 magnification, hematoxylin-eosin stain).

may manifest as coronary ischemia from coronary artery endothelial thrombi and profound elevation in cardiac enzymes which are often prevented with aspirin and intensive anti-ischemic medication with nitrates and $\beta$-blockers [56]. Acute coronary syndrome is believed to equally result from attendant vascular endothelial dysfunction of the coronary artery and peripheral vasculature, and this endothelial dysfunction is considered an early indicator of atherosclerosis $[57,58]$. The histological findings of increased coronary artery endothelial thickening and microthrombi in the $T Z M$-only treated rat hearts are indicative of the full experimental induction of TZM-related arteriosclerosis and TZMinduced cardiotoxicity. Vitamin $\mathrm{C}$ has previously been reported to improve endothelial function of conduct arteries in patients with chronic cardiac failure [59]. However, the fact that oral pretreatments with $C V E$ and $I G E$ effectively improved these histological lesions is strongly reflective of the therapeutic potential effects of these extracts against $T Z M$-associated endothelial dysfunction.
Oxidative stress (the shift in the balance between oxidants and antioxidants in favor of oxidants) is the net result of an imbalance between ROS production and destruction (the latter being regulated by antioxidant defense system) $[60,61]$. ROS (free radicals and non-radicals) are produced from molecular oxygen as a result of normal cellular metabolism and the 3 major ROS that are of physiological significance are superoxide anion $\left(\mathrm{O}_{2}^{-\cdot}\right)$, hydroxyl radical $(\bullet \mathrm{OH})$, and hydrogen peroxide $\left(\mathrm{H}_{2} \mathrm{O}_{2}\right)$ [60]. Oxidative stress is a consequence of an increased generation of these free radicals and/or reduced physiological activity of antioxidant defenses against free radicals. In containing the activities of the ROS, the body system has evolved an innate antioxidant system to mitigate the possible deleterious effects of oxidative stress on the body organs/systems $[60,62,63]$. The antioxidant systems are basically of two types, namely, enzymatic antioxidants which include SOD, CAT, GSH Px, GSTs, and heme oxygenase- 1 and nonenzymatic antioxidants which include vitamins (vitamins $\mathrm{C}$ and $\mathrm{E}$ ), $\beta$-carotene, uric acid, and GSH, a tripeptide (L- $\gamma$-glutamyl-L-cysteinyl-L-glycine) that comprise a thiol (sulfhydryl) group (e.g., thioredoxin-1 (Trx-1)) [60, 64]. These antioxidant systems are known to mediate their antioxidant activities via several mechanisms which include the inhibition of free radical formations; protection of cells against apoptosis by interacting with proapoptotic and antiapoptotic signaling pathways; regulation and activation of several transcription factors, such as AP-1, NF- $\kappa \mathrm{B}$, and Sp-1; superoxide and oxygen-free radical scavenging activities [65-70]. Pleiotropic deleterious effects of oxidative stress are observed in numerous disease states and are also implicated in a variety of drug-induced toxicities. Identifiable drugs are alkylating anthracycline antineoplastic agents (doxorubicin), antiretroviral (azidovudine), antiinflammatory (diclofenac), platinum-based antineoplastic agent (cisplatin), antipsychotic (chlorpromazine) [71], and most recently, a HER2 directed monoclonal antibody (trastuzumab) [7, 72]. However, the effectiveness of conventional cytotoxic drugs is largely based on the generation of ROS and consequently on the increase of oxidative stress that exceeds the reduction capacity of cancerous tissue, resulting in apoptotic cell death [73], and most of the adverse effects emanating from chemotherapy result from excess ROS 


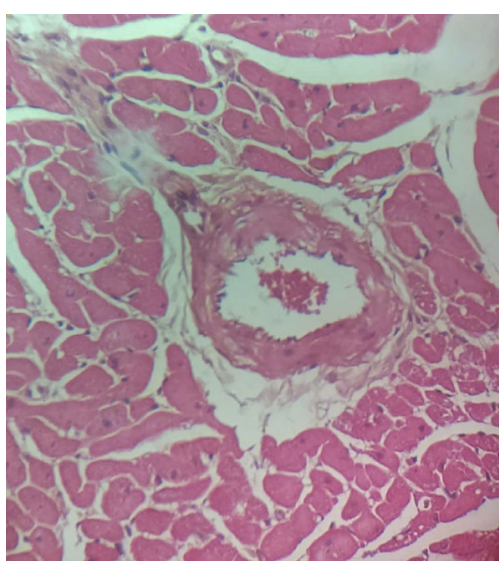

Figure 2: A cross-sectional representative of the normal rat heart showing normal cardiac histoarchitecture ( $\mathrm{x} 400$ magnification, hematoxylin-eosin stain).

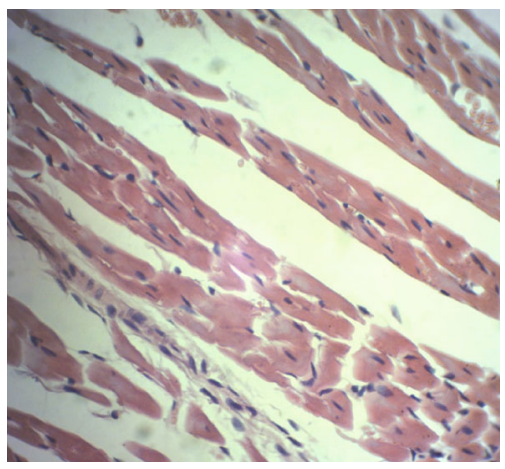

Figure 3: A cross-sectional representative of the $400 \mathrm{mg} / \mathrm{kg} /$ day of $C V E$ treated-rat heart showing normal cardiac histoarchitecture with mild pericardiac fat deposit (x400 magnification, hematoxylineosin stain).

production in healthy tissues, such as anthracyclinemediated cardiotoxicity, and nephrotoxicity triggered by platinum compounds [74, 75] which are mainly based on the interaction of $\mathrm{OH}^{\bullet}$ with target tissue DNA [76, 77]. TZM has been reported to potentiate cardiomyocyte toxicity through a "dual-hit" mechanism, which includes alterations in antiapoptotic signalling pathways in cardiomyocytes, inhibition of the neuregulin-1 survival signaling pathway, and angiotensin II-induced activation of NADPH oxidase, with the ability to further increase reactive oxygen species production, ultimately resulting in dilated cardiomyopathy $[78,79]$.

The present study showed that TZM had significant effects on the oxidative stress markers such as SOD, CAT, GST, and GSH whose activities and levels in the treated cardiac tissues were suppressed while the cardiac tissue activities and levels of GPx and MDA were profoundly elevated. These results are similar to others previously reported [31, 80, 81]. TZM induces cardiomyocyte toxicity through a mitochondrial pathway depending on ROS production and oxidative stress. TZM activates proapoptotic proteins such as Bax and induces $m P T P$ opening, and these eventually result in

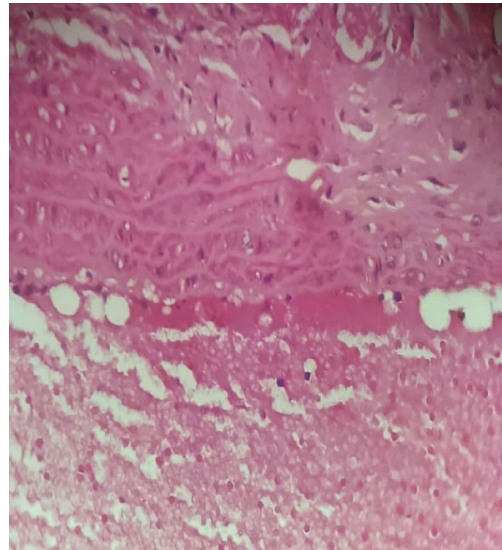

FIGURE 4: A cross-sectional representative of the $400 \mathrm{mg} / \mathrm{kg} /$ day of IGE treated-rat heart showing normal cardiac histoarchitecture (x400 magnification, hematoxylin-eosin stain).

mitochondrial defects and dysfunctions [82]. Classes of conventional drugs such as angiotensin-converting enzyme inhibitor (ACEI), angiotensin receptor blocker (ARB), mineralocorticoid receptor antagonist (MRA), nonsteroidal anti-inflammatory drug (NSAID), and lecithinized human recombinant superoxide dismutase (PC-SOD) have been reported to offer cardioprotection against DOX-mediated cardiotoxicities [83]. Natural antioxidant supplements such as coenzyme Q10 [84] and N-acetylcysteine (administered either alone or with vitamins $\mathrm{E}$ and $\mathrm{C}$ ) [85] have been reported to mitigate anthracycline- (doxorubicin-) mediated left ventricular dysfunction and remodeling while melatonin [86] and levocarnitine [87] have also been tested in the clinical setting with positive results. Similarly, plant-derived small molecules such as arjunolic acid, anthocyanins, apigenin, avicularin, berberine, baicalein, caffeic acid, gingerol, ginsenosides, calceolarioside, cannabidiol, carotenoids, chrysin, catechins, chrysoeriol, curcumin, eugenol, frederine, diosgenin, hesperidin, and kaempferol have all been reported to positively mitigate doxorubicin-mediated cardiotoxicity [88]. However, ours is the first to report the mitigating effect of plant extracts and indeed Clerodendrum volubile leaf and Irvingia gabonensis seed extracts against TZM-induced cardiotoxicity. Plant secondary metabolites especially polyphenols such as flavonoids, epicatechin, catechin, anthocyanidins, epigallocatechin gallate, carotenoids, terpenoids, sesquiterpenoids, and unsaturated fatty acids have been reported to protect against the deleterious effects of oxidative stress, reduce blood pressure, and improve endothelial dysfunction through several mechanisms $[89,90]$ which include activation of eNOS and reduced endothelial ET-1 secretion which are key in NO/cGMP pathway [91-95], as well as through activation of Akt/eNOS pathway [96]. Proanthocyanidins are also known to possess antithrombotic properties that are associated with endothelial protection and inhibition of inflammatory cells adhesion because it decreases P-selectin expression, thus, inhibiting leucocyte recruitment and thrombosis [96-98]. Proanthocyanidins are also known to have anti-inflammatory and antioxidant effects and improve 


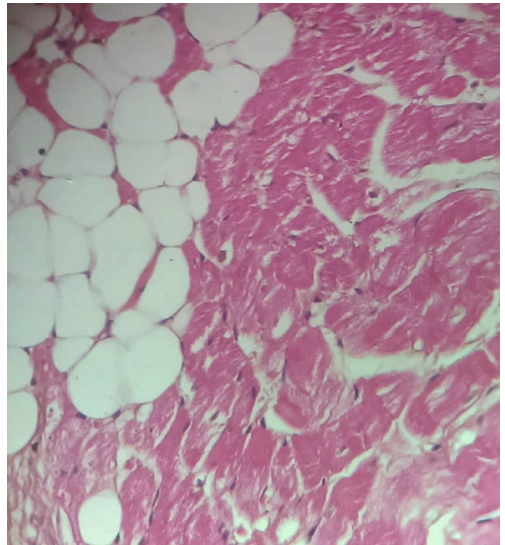

Figure 5: A photomicrograph of cross-sectional representative of $T Z M$ intoxicated rat heart orally pretreated with $20 \mathrm{mg} / \mathrm{kg} /$ day of vit. C showing mild vascular congestion, mild intraparenchymal hemorrhage, and increased pericardial fat thickness (x400 magnification, hematoxylin-eosin stain).

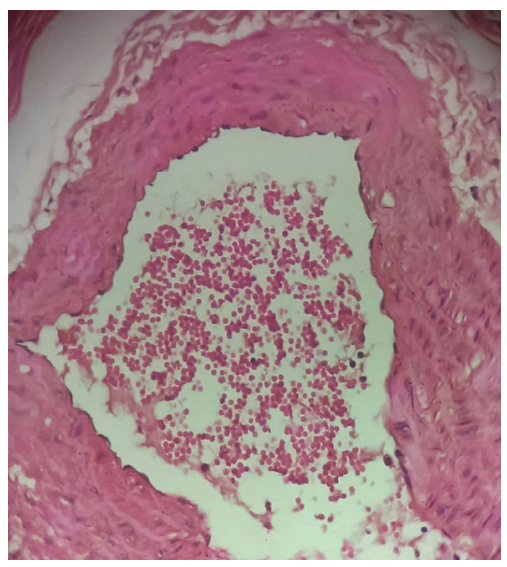

FIGURE 6: A photomicrograph of cross-sectional representative of $T Z M$ intoxicated rat heart treated with $400 \mathrm{mg} / \mathrm{kg} /$ day of $C V E$ showing mild intraparenchymal hemorrhage with thickened coronary arterial wall suggestive of coronary arteriosclerosis ( $\mathrm{x} 400$ magnification, hematoxylin-eosin stain).

circulating HDL-c levels without causing dyslipidemia, thus, exhibiting endothelium-protective, antiatherogenic, and cardioprotective activities [97, 99, 100]. Although coronary artery microthrombi formation was observed histopathologically in the rat hearts intoxicated with TZM but this was for profoundly improved with repeated oral CVE and IGE pretreatments with coronary artery revascularization observed in rat heart pretreated with IGE. CVE and IGE have reported to be abundantly rich in polyphenols and have been attributed to responsible for the high antioxidant activities of the plants $[9,16,17,25,27]$. Thus, the presence of polyphenols in high amounts in these extracts could be responsible for the observed cardioprotection offered against TZM cardiotoxicity. Similarly, oleanolic acid has been reported to be abundantly present in CVE and IGE and is known to decrease oxidative stress, apoptosis, and proteasomal activity following ischemia-reperfusion injury [101], antihyperlipidemic, and cardioprotective effects $[23,102]$. Thus, the presence of

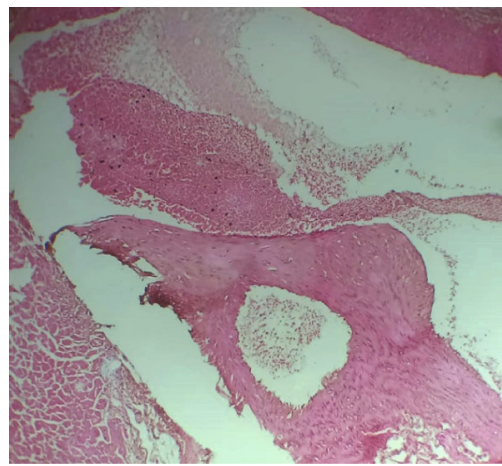

Figure 7: A photomicrograph of cross-sectional representative of $T Z M$ intoxicated rat heart treated with $400 \mathrm{mg} / \mathrm{kg} /$ day IGE showing mild vascular congestion and coronary artery recanalization (x100 magnification, hematoxylin-eosin stain).

this oil and other secondary metabolites could have also contributed to the cardioprotection offered by these extracts.

The clinical use of antioxidants in recent years has gained considerable interest. Epidemiological studies have suggested that diets (fruits and vegetables) that are richly high in antioxidant contents including vitamins $\mathrm{A}, \mathrm{C}$, and $\mathrm{E}$ and other phenolic contents might help decrease the risk of cardiovascular diseases (such as atherosclerosis, preeclampsia, or hypertension) and other chronic noncommunicable diseases such as diabetes mellitus, whose etiopathogenesis are thought to be mediated by oxidative stress [103]. Similarly, antioxidants have been documented to have useful clinical application in ameliorating drugs and xenobiotic toxicity. Drug, xenobiotic and environmental pollutant biotransformation results in the overproduction of free radicals in the body leading to lipid peroxidation, oxidative stress, and oxidative damage [104]. The ROS, thus, generated either directly or indirectly through the mediation of oxidative and inflammatory signals, disrupt the cellular equilibrium, and cause mitogenesis, mutagenesis, genotoxicity, and cytotoxicity and form the underlying pathophysiology for diseases such as diabetes, hypertension, atherosclerosis, cancer, Parkinsonism, and Alzheimer's disease [104]. However, studies have shown the benefit of antioxidants in protection against drug- and xenobiotic-induced toxicities. For example, the beneficial role of citrus fruit-derived flavonoid (diosmin) in ameliorating and preventing methotrexate-induced oxidative and inflammatory markers, suggesting the promising protective role of diosmin against methotrexate-induced toxicities in patients with cancer and autoimmune diseases have been reported [105]. Similarly, the protective effects of green tea (Camellia sinensis) on nicotine exposure-induced oxidative damage in mice leading to behavioral alterations including physical development, neuromotor maturation, and behavioral performance in newborn male and female mice have been demonstrated [106]. In another study, the cardioprotective role of the flavonoid and phenolic contents of Murraya koenigii (L.) Spreng. leaf extract against doxorubicininduced cardiotoxicity in rat model was reported, indicating the protective potential of Murraya koenigii (L.) Spreng. leaf extract as an adjuvant therapy with doxorubicin [107]. Thus, in line with the above, the flavonoid and phenolic contents in 
$C V E$ and IGE could be useful adjuvant therapy to ameliorate TZM-mediated cardiotoxicity.

The chemopreventive role of the standard antioxidant drug, vitamin C, in doxorubicin/trastuzumab-mediated cardiotoxicity which are primarily mediated via reactive oxidative stress, nitrosative stress, and inflammatory pathways is well documented (Fujita et al., 1982; Shimpo et al., 1991; Vincent et al., 2013; Akolkar et al., 2017; Singh et al., 2018; Carrasco et al., 2020) [108-113]. Vitamin C and its derivatives were reported to prevent myocardial lipoperoxidation and subsequent doxorubicin-mediated cardiomyopathy, thus, prolonged the life expectancy of experimental animals treated with doxorubicin $[108,109]$. Vitamin $C$ was also reported to mediate its cardioprotection via multimodal mechanisms which include reduced protein carbonyl formation, NOS activity, protein nitrosylation, iNOS expression, expression of apoptotic proteins (Bax, Bnip-3, Bak, and caspase-3), as well as decreased cardiac TNF- $\alpha$, IL- $1 \beta$, and IL-6 levels and increased Vitamin C transporter proteins (SVCT-2 and GLUT-4) [114]. Thus, the results of this study are in complete agreement with those of earlier studies where vitamin $\mathrm{C}$ pretreatments either prevented or ameliorated the deleterious effects of TZM-induced myocardial cellular oxidative damage.

Another notable finding of this study is the effect of TZM and the oral pretreatments with CVE, IGE, and Vit. C. TZM, unlike anthracycline cytotoxic agents, have been reported not to alter the lipid profile of cancer patients on it although preexisting diabetes mellitus, dyslipidemia, and obesity along with a number of cardiovascular risk factors and comorbidities are known to increase the propensity for cardiotoxicity in cancer patients on anthracycline/TZM therapy (Jawa et al., 2016; Kosalka et al., 2019; Abdel-Rasaq et al., 2019; Georgiadis et al., 2020) [115-118]. Going by the fact that repeated TZM injections did not significantly alter the complete lipids profile including the cardiovascular disease risk indices including AI and CRI of treated rats strongly indicated our result to be in tandem with earlier studies. AI is known to be a strong, reliable, and independent predictor of ischemic heart diseases including coronary artery disease and acute myocardial infarction (Cai et al., 2017; Kazemi et al., 2018; Gómez-Âlvarez et al., 2020) [119-121]. AI is known to be a better predictor of coronary artery disease than traditional lipid parameters and other lipid ratios such as CRI and lipoprotein combined index (Cai et al., 2017) [119]. AI also reflects the lipid-driven inflammatory state in acute coronary syndrome (Zhan et al., 2016) [122]. The mere fact that TZM did not alter the value of this predictor is an indication that TZM does not mediate its cardiac dysfunction via the atherogenic mechanism. Similarly, this further strengthens the fact that $C V E$ and IGE possess cardioprotective potentials.

\section{Conclusion}

Overall, results of our study for the first time showed that CVE and IGE effectively attenuated TZM-induced cardiotoxicity and their cardioprotective activities were mediated via antioxidant, free radical scavenging, antilipoperoxidation mechanisms although their antithrombotic mechanism remains plausible but more studies are required in this direction.

\section{Abbreviations}

Akt/eNOS: Akt-dependent phosphorylation of endothelial nitric oxide synthase

AI: $\quad$ Atherogenic index

AST: $\quad$ Aspartate transaminase

Bak: $\quad$ B-cell associated $\mathrm{k}$ protein

Bax: $\quad$ B-cell associated $x$ protein

Bnip3: $\quad$ Bcl-2 adenovirus E1B $19 \mathrm{kDa}$-interacting protein 3

CAT: $\quad$ Catalase

CRI: $\quad$ Coronary artery index

cTn I: $\quad$ Cardiac troponin I

CVE: $\quad$ Clerodendrum volubile ethanol leaf extract

DMSO: $\quad$ Dimethyl sulfoxide

DPPH: $\quad$ 1,1-diphenyl-2-picrylhydrazyl

DTNB: 5,5-dithiobisnitro benzoic acid

eNOS: $\quad$ Endothelial nitric oxide synthase

ET-1: $\quad$ Endothelin-1

GLUT-4: Glucose transporter protein-4

GPx: $\quad$ Glutathione peroxidase

GSH: $\quad$ Reduced glutathione

GST: $\quad$ Glutathione S-transferase

HCl: $\quad$ Hydrochloric acid

HDL-c: $\quad$ High-density lipoprotein cholesterol

IGE: Irvingia gabonensis ethanol seed extract

IL-1 $\beta$ : Interleukin-1 beta

IL-6: $\quad$ Interleukin-6

iNOS: $\quad$ Induced nitric oxide synthase

i.p.: Intraperitoneal

KCl: $\quad$ Potassium chloride

LDH: $\quad$ Lactate dehydrogenase

LDL-c: $\quad$ Low-density lipoprotein cholesterol

MDA: $\quad$ Malondialdehyde

mPTP: $\quad$ Mitochondrial permeability transition pore

NO/cGMP: Nitric oxide-cyclic guanosine monophosphate

NOS: $\quad$ Nitric oxide synthase

p.o.: $\quad$ Per os

$\% \Delta$ wt.: $\quad$ Percentage change in weight

RHW: $\quad$ Relative heart weight

ROS: $\quad$ Reactive oxygen species

S.D.: $\quad$ Standard deviation of the mean

S.E.M.: $\quad$ Standard error of the mean

SOD: $\quad$ Superoxidase dismutase

SVCT-2: $\quad$ Sodium-dependent vitamin C cotransporter isoform 2

TBA: $\quad$ Thiobarbituric acid

TC: $\quad$ Total cholesterol

TCA: $\quad$ Tricarboxylic acid

TG: $\quad$ Triglyceride

TNF- $\alpha$ : Tumor necrosis factor-alpha

TZM: $\quad$ Trastuzumab (r-DNA origin)

UNILORIN: University of Ilorin

UV: $\quad$ Ultraviolet

Vit. C: $\quad$ Vitamin C

VLDL-c: Very low-density lipoprotein cholesterol. 


\section{Data Availability}

Answer: Yes. Comment.

\section{Conflicts of Interest}

The authors have none to declare.

\section{Authors' Contributions}

Olufunke Olorundare designed the experimental protocol for this study and was involved in the manuscript writing; Adejuwon Adeneye supervised the research, analyzed data, and wrote the manuscript; Akinyele Akinsola is an M.Sc. student in Olufunke Olorundare's laboratory who performed the laboratory research; Sunday Soyemi and Alban Mgbehoma independently read and interpreted the histopathological slides of the cardiac tissues prepared; James Ntambi and Hasan Mukhtar are our collaborator in the U.S.A. who read through the manuscript.

\section{Acknowledgments}

The authors deeply appreciate the technical assistance provided by the Laboratory Manager, Dr. Sarah John-Olabode and other staff of the Laboratory Services, AFRIGLOBAL MEDICARE, Mobolaji Bank Anthony Branch Office, Ikeja, Lagos, Nigeria, in assaying for the serum cardiac biomarkers and lipid profile. Similarly, the technical support of staff of LASUCOM Animal House for the care of the Experimental Animals used for this study and Mr. Sunday O. Adenekan of BIOLIFE CONSULTS in the area of oxidative stress markers analysis are much appreciated. This research was funded by Tertiary Education Trust Fund (TETFUND) Nigeria, through its National Research Fund (TETFUND/NRF/UIL/ILORIN/STI/VOL.1/B2.20.12) as a collaborative research award to both Professors Olufunke Olorundare and Hasan Mukhtar.

\section{References}

[1] N. Mohan, J. Jiang, M. Dokmanovic, and W. J. Wu, “Trastuzumab-mediated cardiotoxicity: current understanding, challenges, and frontiers," Antibody Therapeutics, vol. 1, no. 1, pp. 13-17, 2018.

[2] J. J. Gemmete and S. K. Mukherji, "Trastuzumab (Herceptin)," American Journal of Neuroradiology, vol. 32, no. 8, pp. 13731374, 2011.

[3] A. A. Onitilo, J. M. Engel, and R. V. Stankowski, "Cardiovascular toxicity associated with adjuvant trastuzumab therapy: prevalence, patient characteristics, and risk factors," Therapeutic Advances in Drug Safety, vol. 5, no. 4, pp. 154-166, 2014.

[4] M. F. Rimawi, R. Schiff, and C. K. Osborne, "Targeting HER2 for the treatment of breast cancer," Annual Review of Medicine, vol. 66, no. 1, pp. 111-128, 2015.

[5] Y. You, Z. Xu, and Y. Chen, "Doxorubicin conjugated with a trastuzumab epitope and an MMP-2 sensitive peptide linker for the treatment of HER2-positive breast cancer," Drug Delivery, vol. 25, no. 1, pp. 448-460, 2018.
[6] N. Mohan, Y. Shen, Y. Endo, M. K. ElZarrad, and W. J. Wu, "Trastuzumab, but not pertuzumab, dysregulates HER2 signaling to mediate inhibition of autophagy and increase in reactive oxygen species production in human cardiomyocytes," Molecular Cancer Therapeutics, vol. 15, no. 6, pp. 1321-1331, 2016.

[7] N. Mohan, J. Jiang, and W. J. Wu, "Implications of autophagy and oxidative stress in trastuzumab-mediated cardiac toxicities," Austin Pharmacology \& Pharmaceutics, vol. 2, no. 1, p. 1005, 2017.

[8] Y.-Y. Wu, T.-C. Huang, T.-N. Tsai et al., "The clinical efficacy and cardiotoxicity of fixed-dose monthly trastuzumab in HER2-positive breast cancer: A single institutional analysis," PLoS One, vol. 11, no. 3, article e0151112, 2016.

[9] S. A. Adefegha and G. Oboh, "Antioxidant and inhibitory properties ofClerodendrum volubileleaf extracts on key enzymes relevant to non-insulin dependent diabetes mellitus and hypertension," Journal of Taibah University for Science, vol. 10, no. 4, pp. 521-533, 2018.

[10] O. L. Erukainure, R. M. Hafizur, N. Kabir et al., "Suppressive effects of Clerodendrum volubile P. Beauv. [Labiatae] methanolic extract and its fractions on type 2 diabetes and its complications," Frontiers in Pharmacology, vol. 9, p. 8, 2018.

[11] O. L. Erukainure, O. A. T. Ebuehi, I. M. Choudhary et al., "Iridoid glycoside from the leaves of Clerodendrum volubile Beauv. shows potent antioxidant activity against oxidative stress in rat brain and hepatic tissues," Journal of Dietary Supplements, vol. 11, no. 1, pp. 19-29, 2014.

[12] A. Fred-Jaiyesimi and A. Adekoya, "Pharmacognostic studies and anti-inflammatory activities of Clerodendrum volubile $\mathrm{P}$ Beauv leaf," International Journal of Phytomedicine, vol. 4, no. 3, pp. 414-418, 2012.

[13] O. L. Erukainure, M. Z. Zaruwa, M. I. Choudhary et al., "Dietary fatty acids from leaves ofClerodendrum VolubileInduce cell cycle arrest, downregulate matrix metalloproteinase-9 expression, and modulate redox status in human breast cancer," Nutrition and Cancer, vol. 68, no. 4, pp. 634-645, 2016.

[14] O. L. Erukainure, M. A. Mesaik, O. Atolani, A. Muhammad, C. I. Chukwuma, and M. S. Islam, "Pectolinarigenin from the leaves of Clerodendrum volubile shows potent immunomodulatory activity by inhibiting T- cell proliferation and modulating respiratory oxidative burst in phagocytes," Biomedicine \& Pharmacotherapy, vol. 93, pp. 529-535, 2017.

[15] S. Afolabi, O. Olorundare, G. Gyebi et al., "Cytotoxic potentials of Clerodendrum volubile against prostate cell lines and its possible proteomic targets," Journal of Clinical Nutrition and Food Sciences, vol. 2, no. 2, pp. 46-53, 2019.

[16] C. T. Senjobi, T. R. Fasola, and P. I. Aziba, "Phytochemical and analgesic evaluation of methanol leaf extract of Clerodendrum volubile Linn," IFE Journal of Science, vol. 19, no. 1, pp. 141-145, 2017.

[17] A. A. Ajao, O. M. Oseni, O. T. Oladipo, Y. A. Adams, Y. O. Mukaila, and A. A. Ajao, "Clerodendrum volubile P. Beauv (Lamiaceae), an underutilized indigenous vegetable of utmost nutritive and pharmacological importance," Beni-Suef University Journal of Basic and Applied Sciences, vol. 7, no. 4, pp. 606-611, 2018.

[18] H. M. Burkill, The Useful Plants of West Tropical Africa, vol. 2, Royal Botanic Gardens, Kew, London, 1985.

[19] L. Karalliedde and I. Gawarammana, Traditional Herbal Medicines - a Guide to the Safer Use of Herbal Medicines, Hammersmith Press, London, 2008. 
[20] J. I. Okogun, Drug discovery through ethnobotany in Nigeria: some results. In: advances in Phytomedicine - Ethnomedicine and drug discovery, M. M. Iwu and J. C. Wootton, Eds., vol. 1, Elsevier, London, 2002.

[21] J. Sun and P. Chen, "Ultra high-performance liquid chromatography with high-resolution mass spectrometry analysis of African mango (Irvingia gabonensis) seeds, extract, and related dietary supplements," Journal of Agricultural and Food Chemistry, vol. 60, no. 35, pp. 8703-8709, 2012.

[22] U. F. Ezeruike and J. M. Prieto, "The use of plants in the traditional management of diabetes in Nigeria: pharmacological and toxicological considerations," Journal of Ethnopharmacology, vol. 155, no. 2, pp. 857-924, 2014.

[23] F. M. Awah, P. N. Uzoegwu, P. Ifeonu et al., "Free radical scavenging activity, phenolic contents and cytotoxicity of selected Nigerian medicinal plants," Food Chemistry, vol. 131, no. 4, pp. 1279-1286, 2012.

[24] D. C. Don Lawson, "Proximate analysis and phytochemical screening of Irvingia gabonensis (Ogbono cotyledon)," Biomedical Journal of Scientific and Technical Research, vol. 5, no. 4, pp. 4643-4646, 2018.

[25] G. K. Mahunu, L. Quansa, H. E. Tahir, and A. A. Mariod, "Irvingia gabonensis: phytochemical constituents, bioactive compounds, traditional and medicinal uses," in Wild Fruits: Composition, Nutritional Value and Products, A. Mariod, Ed., Springer, Cham, 2019.

[26] O. Oladimeji and T. O. Fasuan, "Characterization of Irvingia gambonensis (Ogbono) soup and optimization of process variables," International Journal of Food Engineering and Technology, vol. 2, no. 2, pp. 41-50, 2019.

[27] O. O. Ekpe, C. O. Nwaehujor, C. E. Ejiofor, W. Arikpo Peace, E. Woruji Eliezer, and T. Amor Emmanuel, "Irvingia gabonensis seeds extract fractionation, its antioxidant analyses and effects on red blood cell membrane stability," Pharmacology, vol. 1, pp. 337-353, 2019.

[28] A. O. Akinsola, Vasorelaxant and Cardioprotective Properties of Clerodendrum Volubile Leaf Extract on DoxorubicinInduced Toxicities in Wistar Rats A M.Sc. Pharmacology Dissertation submitted to the Postgraduate School, University of Ilorin, Ilorin, Nigeria, 2019.

[29] National Research Council (US) Committee for the Update of the Guide for the Care and Use of Laboratory Animals, Guide for the Care and Use of Laboratory Animals, The National Academies Press, Washington D.C., U.S.A, 2011.

[30] K. A. Poon, K. Flagella, J. Beyer et al., "Preclinical safety profile of trastuzumab emtansine (T-DM1): mechanism of action of its cytotoxic component retained with improved tolerability," Toxicology and Applied Pharmacology, vol. 273, no. 2, pp. 298-313, 2013.

[31] G. Riccio, S. Antonucci, C. Coppola et al., "Ranolazine attenuates trastuzumab-induced heart dysfunction by modulating ROS production," Frontiers in Physiology, vol. 9, no. 38, 2018.

[32] N. W. Tietz, Textbook of Clinical Chemistry, C. A. Burtis and E. R. Ashwood, Eds., W. B. Saunders, Philadephia, U.S.A, 1999.

[33] R. D. Abbott, P. W. Wilson, W. B. Kannel, and W. P. Castelli, "High density lipoprotein cholesterol, total cholesterol screening, and myocardial infarction. The Framingham Study," Arteriosclerosis, vol. 8, no. 3, pp. 207-211, 1988.

[34] S. Alladi and K. R. Shanmugasundaram, "Induction of hypercholesterolemia by supplementing soy protein with acetate generating amino acids," Nutrition Reports International, vol. 40, pp. 893-899, 1989.

[35] F. Paoletti, D. Aldinucci, A. Mocali, and A. Caparrini, “A sensitive spectrophotometric method for the determination of superoxide dismutase activity in tissue extracts," Analytical Biochemistry, vol. 154, no. 2, pp. 536-541, 1986.

[36] M. H. Hadwan, "Simple spectrophotometric assay for measuring catalase activity in biological tissues," BMC Biochemistry, vol. 19, no. 1, p. 7, 2018.

[37] I. Rahman, A. Kode, and S. K. Biswas, "Assay for quantitative determination of glutathione and glutathione disulfide levels using enzymatic recycling method," Nature Protocols, vol. 1, no. 6, pp. 3159-3165, 2006.

[38] B. Faraji, H. K. Kang, and J. L. Valentine, "Methods compared for determining glutathione peroxidase activity in blood," Clinical Chemistry, vol. 33, no. 4, pp. 539-543, 1987.

[39] J. G. Vontas, A. A. Enayati, G. J. Small, and J. Hemingway, "A simple biochemical assay for glutathione S-transferase activity and its possible field application for screening glutathione S-transferase-based insecticide resistance," Pesticide Biochemistry and Physiology, vol. 68, no. 3, pp. 184-192, 2000.

[40] J. A. Buege and S. D. Aust, "Microsomal lipid peroxidation," Methods in Enzymology, vol. 52, pp. 302-310, 1978.

[41] M. Slaoui and L. Fiette, "Histopathology procedures: from tissue sampling to histopathological evaluation," Methods in Molecular Biology, vol. 691, pp. 69-82, 2011.

[42] D. L. Keefe, "Trastuzumab-associated cardiotoxicity," Cancer, vol. 95, no. 7, pp. 1592-1600, 2002.

[43] S. Karmakar, R. Dixit, A. Nath, S. Kumar, and S. Karmakar, "Dilated cardiomyopathy following trastuzumab chemotherapy," Indian Journal of Pharmacology, vol. 44, no. 1, pp. 131133, 2012.

[44] A. Sandoo, G. D. Kitas, and A. R. Carmichael, "Endothelial dysfunction as a determinant of trastuzumab-mediated cardiotoxicity in patients with breast cancer," Anticancer Research, vol. 34, no. 3, pp. 1147-1151, 2014.

[45] B. M. Reddy, H. S. Weintraub, and A. Z. Schwartzbard, "Ranolazine: a new approach to treating an old problem," Texas Heart Institute Journal, vol. 37, no. 6, pp. 641-647, 2010.

[46] M. Reed and D. Nicolas, "Ranolazine" in: StatPearls [Internet], StatPearls Publishing, Treasure Island (FL), 2019, https://www.ncbi.nlm.nih.gov/books/NBK507828/.

[47] K. B. Wallace, E. Hausner, E. Herman et al., "Serum troponins as biomarkers of drug-induced cardiac toxicity," Toxicologic pathology, vol. 32, pp. 106-121, 2016.

[48] D. Singh, A. Thakur, and W. H. W. Tang, "Utilizing cardiac biomarkers to detect and prevent chemotherapy-induced cardiomyopathy," Current Heart Failure Reports, vol. 12, no. 3, pp. 255-262, 2015.

[49] A. Sugaya, S. Ishiguro, S. Mitsuhashi et al., "Interstitial lung disease associated with trastuzumab monotherapy: a report of 3 cases," Molecular and Clinical Oncology, vol. 6, no. 2, pp. 229-232, 2017.

[50] R. Simões, L. M. Silva, A. L. V. M. Cruz, V. G. Fraga, A. de Paula Sabino, and K. B. Gomes, "Troponin as a cardiotoxicity marker in breast cancer patients receiving anthracyclinebased chemotherapy: a narrative review," Biomedicine \& Pharmacotherapy, vol. 107, pp. 989-996, 2018.

[51] W. Zhu, L. Ma, J. Qian et al., “The molecular mechanism and clinical significance of LDHA in HER2-mediated progression 
of gastric cancer," American Journal of Translational Research, vol. 10, no. 7, pp. 2055-2067, 2018.

[52] M. Sternberg, E. Pasini, C. Chen-Scarabelli et al., "Elevated cardiac troponin in clinical scenarios beyond obstructive coronary artery disease," Medical Science Monitor, vol. 25, pp. 7115-7125, 2019.

[53] K. Altundag, "More predictive markers were identified for trastuzumab-induced cardiotoxicity," Medical Oncology, vol. 35 , no. $1,2018$.

[54] E. Jobard, O. Trédan, T. Bachelot et al., "Longitudinal serum metabolomics evaluation of trastuzumab and everolimus combination as pre-operative treatment for HER-2 positive breast cancer patients," Oncotarget, vol. 8, no. 48, pp. 83570-83584, 2017.

[55] W. Tian, Y. Yao, G. Fan et al., "Changes in lipid profiles during and after (neo)adjuvant chemotherapy in women with early-stage breast cancer: A retrospective study," PLoS ONE, vol. 14, no. 8, article e0221866, 2019.

[56] A. K. Dimos, P. N. Stougianoss, and A. G. Trikas, "First, do no harm chemotherapy or healthy heart?," Hellenic Journal of Cardiology, vol. 53, no. 2, pp. 127-136, 2012.

[57] A. Lerman and A. M. Zeiher, "Endothelial function: cardiac events," Circulation, vol. 111, no. 3, pp. 363-368, 2005.

[58] L. Morbidelli, S. Donnini, and M. Ziche, "Targeting endothelial cell metabolism for cardio-protection from the toxicity of antitumor agents," Cardio-Oncology, vol. 2, no. 1, 2016.

[59] B. Hornig, N. Arakawa, C. Kohler, and H. Drexler, "Vitamin $\mathrm{C}$ improves endothelial function of conduit arteries in patients with chronic heart failure," Circulation, vol. 97, no. 4, pp. 363-368, 1998.

[60] E. Birben, U. M. Sahiner, C. Sackesen, S. Erzurum, and O. Kalayci, "Oxidative stress and antioxidant defense," World Allergy Organization Journal, vol. 5, no. 1, pp. 9-19, 2012.

[61] B. Poljsak, D. Šuput, and I. Milisav, "Achieving the balance between ROS and antioxidants: when to use the synthetic antioxidants," Oxidative Medicine and Cellular Longevity, vol. 2013, Article ID 956792, 11 pages, 2013.

[62] L. He, T. He, S. Farrar, L. Ji, T. Liu, and X. Ma, "Redox homeostasis by elimination of reactive oxygen species," Cellular Physiology and Biochemistry, vol. 2012, article 645460, 2012.

[63] I. S. Harris and G. M. DeNicola, "The complex interplay between antioxidants and ROS in cancer," Trends in Cell Biology, vol. 30, no. 6, pp. 440-451, 2020.

[64] R. Masella, R. di Benedetto, R. Varì, C. Filesi, and C. Giovannini, "Novel mechanisms of natural antioxidant compounds in biological systems: involvement of glutathione and glutathione-related enzymes," The Journal of Nutritional Biochemistry, vol. 16, no. 10, pp. 577-586, 2005.

[65] V. W. Bunker, "Free radicals, antioxidants and ageing," Medical Laboratory Sciences, vol. 49, no. 4, pp. 299-312, 1992.

[66] J. D. Hayes and D. J. Pulford, "The glutathione S-transferase supergene family: regulation of GST and the contribution of the isoenzymes to cancer chemoprotection and drug resistance," Critical Reviews in Biochemistry and Molecular Biology, vol. 30, pp. 445-600, 2008.

[67] J. D. Hayes and L. I. McLellan, "Glutathione and glutathionedependent enzymes represent a co-ordinately regulated defence against oxidative stress," Free Radical Research, vol. 31, pp. 273-300, 2009.
[68] D. A. Dickinson and H. J. Forman, "Glutathione in defense and signaling: lessons from a small thiol," Annals of the New York Academy of Sciences, vol. 973, no. 1, pp. 488-504, 2002.

[69] S.-G. Cho, Y. H. Lee, H.-S. Park et al., "Glutathione Stransferase mu modulates the stress activated signals by suppressing apoptosis signal-regulating kinase 1," The Journal of Biological Chemistry, vol. 276, no. 16, pp. 12749-12755, 2001.

[70] A. El-Agamey, G. M. Lowe, D. J. McGarvey et al., "Carotenoid radical chemistry and antioxidant/pro-oxidant properties," Archives of Biochemistry and Biophysics, vol. 430, no. 1, pp. 37-48, 2004.

[71] D. G. Deavall, E. A. Martin, J. M. Horner, and R. Roberts, "Drug-induced oxidative stress and toxicity," Journal of toxicology, vol. 2012, Article ID 645460, 13 pages, 2012.

[72] H. R. Teppo, Y. Soini, and P. Karihtala, "Reactive oxygen species-mediated mechanisms of action of targeted cancer therapy," Oxidative Medicine and Cellular Longevity, vol. 2017, 11 pages, 2017.

[73] S. A. Castaldo, J. R. Freitas, N. V. Conchinha, and P. A. Madureira, "The tumorigenic roles of the cellular REDOX regulatory systems," Oxidative Medicine and Cellular Longevity, vol. 2016, Article ID 8413032, 17 pages, 2016.

[74] P. Angsutararux, S. Luanpitpong, and S. Issaragrisil, “Chemotherapy-induced cardiotoxicity: overview of the roles of oxidative stress," Oxidative Medicine and Cellular Longevity, vol. 2015, Article ID 795602, 13 pages, 2015.

[75] T. Karasawa and P. S. Steyger, "An integrated view of cisplatin-induced nephrotoxicity and ototoxicity," Toxicology Letters, vol. 237, no. 3, pp. 219-227, 2015.

[76] A. C. Begg, F. A. Stewart, and C. Vens, "Strategies to improve radiotherapy with targeted drugs," Nature Reviews. Cancer, vol. 11, no. 4, pp. 239-253, 2011.

[77] E. C. Halperin, L. W. Brady, C. A. Perez, and D. E. Wazer, Perez \& Brady's Principles and Practice of Radiation Oncology, LWW, Wolters Kluwer Health/Lippincott Williams \& Wilkins, 6th edition, 2013.

[78] M. Zeglinski, A. Ludke, D. S. Jassal, and P. K. Singal, "Trastuzumab-induced cardiac dysfunction: a 'dual-hit'," Experimental and Clinical Cardiology, vol. 16, no. 3, pp. 70-74, 2011.

[79] W. Abdel-Razaq, M. Alzahrani, M. Al Yami, F. Almugibl, M. Almotham, and R. Alregaibah, "Risk factors associated with trastuzumab-induced cardiotoxicity in patients with human epidermal growth factor receptor 2-positive breast cancer," Journal of Pharmacy \& Bioallied Sciences, vol. 11, no. 4, pp. 348-354, 2019.

[80] L. G. T. Lemos, V. J. Victorino, A. C. S. A. Herrera et al., "Trastuzumab-based chemotherapy modulates systemic redox homeostasis in women with HER2-positive breast cancer," International Immunopharmacology, vol. 27, no. 1, pp. 8-14, 2015.

[81] S. Gorini, A. de Angelis, L. Berrino, N. Malara, G. Rosano, and E. Ferraro, "Chemotherapeutic drugs and mitochondrial dysfunction: focus on doxorubicin, trastuzumab and sunitinib," Oxidative Medicine and Cellular Longevity, vol. 2018, Article ID 7582730, 15 pages, 2018.

[82] L. I. Gordon, M. A. Burke, A. T. Singh et al., "Blockade of the erbB2 receptor induces cardiomyocyte death through mitochondrial and reactive oxygen species-dependent pathways," 
The Journal of Biological Chemistry, vol. 284, no. 4, pp. 20802087, 2009.

[83] J. E. Finet and W. H. W. Tang, "Protecting the heart in cancer therapy," F1000 Research, vol. 7, article 1566, 2018.

[84] D. Iarussi, U. Auricchio, A. Agretto et al., "Protective effect of coenzyme $_{\mathrm{Q} 10}$ on anthracyclines cardiotoxicity: control study in children with acute lymphoblastic leukemia and nonHodgkin lymphoma," Molecular Aspects of Medicine, vol. 15, pp. S207-S212, 1994.

[85] C. Myers, R. Bonow, S. Palmeri et al., "A randomized controlled trial assessing the prevention of doxorubicin cardiomyopathy by $\mathrm{N}$-acetylcysteine," Seminars in oncology, vol. 10, 1 (Suppl 1), pp. 53-55, 1983.

[86] P. Lissoni, S. Barni, M. Mandalà et al., "Decreased toxicity and increased efficacy of cancer chemotherapy using the pineal hormone melatonin in metastatic solid tumour patients with poor clinical status," European Journal of Cancer, vol. 35, no. 12, pp. 1688-1692, 1999.

[87] R. Waldner, C. Laschan, A. Lohninger et al., "Effects of doxorubicin-containing chemotherapy and a combination with L-carnitine on oxidative metabolism in patients with non-Hodgkin lymphoma," Journal of Cancer Research and Clinical Oncology, vol. 132, no. 2, pp. 121-128, 2006.

[88] S. Ojha, H. Al Taee, S. Goyal et al., "Cardioprotective potentials of plant-derived small molecules against doxorubicin associated cardiotoxicity," Oxidative Medicine and Cellular Longevity, vol. 2016, Article ID 5724973, 19 pages, 2016.

[89] C. P. Bondonno, X. Yang, K. D. Croft et al., "Flavonoid-rich apples and nitrate-rich spinach augment nitric oxide status and improve endothelial function in healthy men and women: a randomized controlled trial," Free Radical Biology and Medicine, vol. 52, no. 1, pp. 95-102, 2012.

[90] N. D. Fisher, S. Hurwitz, and N. K. Hollenberg, "Habitual flavonoid intake and endothelial function in healthy humans," Journal of the American College of Nutrition, vol. 31, no. 4, pp. 275-279, 2012.

[91] K. Kawakami, S. Aketa, H. Sakai, Y. Watanabe, H. Nishida, and M. Hirayama, "Antihypertensive and vasorelaxant effect of water-soluble proanthocyanidins from persimmon leaf tea in spontaneously hypertensive rats," Bioscience Biotechnology and Biochemistry, vol. 75, pp. 1435-1439, 2014.

[92] M. Gómez-Guzmán, R. Jiménez, M. Sánchez et al., "Epicatechin lowers blood pressure, restores endothelial function, and decreases oxidative stress and endothelin-1 and NADPH oxidase activity in DOCA-salt hypertension," Free Radical Biology and Medicine, vol. 52, no. 1, pp. 70-79, 2012.

[93] M. E. Woodcock, W. J. Hollands, A. Konic-Ristic et al., "Bioactive-rich extracts of persimmon, but not nettle, Sideritis, dill or kale, increase eNOS activation and NO bioavailability and decrease endothelin-1 secretion by human vascular endothelial cells," Journal of the Science of Food and Agriculture, vol. 93, no. 14, pp. 3574-3580, 2013.

[94] N. Papageorgiou, D. Tousoulis, A. Katsargyris et al., "Antioxidant treatment and endothelial dysfunction: is it time for flavonoids?," Recent Patents on Cardiovascular Drug Discovery, vol. 8, no. 2, pp. 81-92, 2013.

[95] S. Upadhyay and M. Dixit, "Role of polyphenols and other phytochemicals on molecular signaling," Oxidative Medicine and Cellular Longevity, vol. 2015, Article ID 504253, 15 pages, 2015.
[96] G. Vilahur, T. Padró, L. Casaní et al., "Polyphenol-enriched diet prevents coronary endothelial dysfunction by activating the Akt/eNOS pathway," Revista Española de Cardiología, vol. 68, no. 3, pp. 216-225, 2015.

[97] Y. Zhang, H. Shi, W. Wang et al., "Antithrombotic effect of grape seed proanthocyanidins extract in a rat model of deep vein thrombosis," Journal of Vascular Surgery, vol. 53, no. 3, pp. 743-753, 2011.

[98] J. Minatti, E. Wazlawik, M. A. Hort et al., "Green tea extract reverses endothelial dysfunction and reduces atherosclerosis progression in homozygous knockout low-density lipoprotein receptor mice," Nutrition Research, vol. 32, no. 9, pp. 684-693, 2012.

[99] Y. Shen, N. C. Ward, J. M. Hodgson et al., "Dietary quercetin attenuates oxidant-induced endothelial dysfunction and atherosclerosis in apolipoprotein E knockout mice fed a high-fat diet: a critical role for heme oxygenase-1," Free Radical Biology and Medicine, vol. 65, pp. 908-915, 2013.

[100] W. R. Leifert and M. Y. Abeywardena, "Cardioprotective actions of grape polyphenols," Nutrition Research, vol. 28, no. 11, pp. 729-737, 2008.

[101] S. S. Hassellund, A. Flaa, S. E. Kjeldsen et al., "Effects of anthocyanins on cardiovascular risk factors and inflammation in pre-hypertensive men: a double-blind randomized placebo-controlled crossover study," Journal of Human Hypertension, vol. 27, no. 2, pp. 100-106, 2013.

[102] A. T. Mbaveng, R. Hamm, and V. Kuete, "Harmful and protective effects of terpenoids from African medicinal plants," in Toxicological Survey of African Medicinal Plants, V. Kuete, Ed., pp. 557-576, Elsevier, London, 2014.

[103] R. Rodrigo, C. Guichard, and R. Charles, "Clinical pharmacology and therapeutic use of antioxidant vitamins," Fundamental \& Clinical Pharmacology, vol. 21, no. 2, pp. 111127, 2007.

[104] M. M. Abdel-Daim, Y. M. Moustafa, M. Umezawa, K. V. Ramana, and E. Azzini, "Applications of antioxidants in ameliorating drugs and xenobiotics toxicity: mechanistic approach," Oxidative Medicine and Cellular Longevity, vol. 2017, Article ID 4565127, 2 pages, 2017.

[105] M. M. Abdel-Daim, H. A. Khalifa, A. I. Abushouk, M. A. Dkhil, and S. A. al-Quraishy, "Diosmin attenuates methotrexate-induced hepatic, renal, and cardiac injury: a biochemical and histopathological study in mice," Oxidative Medicine and Cellular Longevity, vol. 2017, Article ID 3281670, 10 pages, 2017.

[106] J. S. Ajarem, G. Al-Basher, A. A. Allam, and A. M. Mahmoud, "Camellia sinensisPrevents perinatal nicotine-induced neurobehavioral alterations, tissue injury, and oxidative stress in male and female mice newborns," Oxidative Medicine and Cellular Longevity, vol. 2017, Article ID 5985219, 16 pages, 2017.

[107] J. A. N. Sandamali, R. P. Hewawasam, K. A. P. W. Jayatilaka, and L. K. B. Mudduwa, "Cardioprotective potential of Murraya koenigii(L.) Spreng. leaf extract against doxorubicininduced cardiotoxicity in rats," eCAM, vol. 2020, article 6023737, pp. 1-16, 2020.

[108] K. Fujita, K. Shinpo, K. Yamada et al., "Reduction of adriamycin toxicity by ascorbate in mice and Guinea pigs," Cancer Research, vol. 42, no. 1, pp. 309-316, 1982.

[109] K. Shimpo, T. Nagatsu, K. Yamada et al., "Ascorbic acid and adriamycin toxicity," The American Journal of Clinical Nutrition, vol. 54, no. 6, pp. 1298S-1301S, 1991. 
[110] D. T. Vincent, Y. F. Ibrahim, M. G. Espey, and Y. J. Suzuki, "The role of antioxidants in the era of cardio-oncology," Cancer Chemotherapy and Pharmacology, vol. 72, no. 6, pp. 1157-1168, 2013.

[111] G. Akolkar, D. da Silva Dias, P. Ayyappan et al., "Vitamin C mitigates oxidative/nitrosative stress and inflammation in doxorubicin-induced cardiomyopathy," AJP Heart and Circulatory Physiology, vol. 313, no. 4, pp. H795-H809, 2017.

[112] K. Singh, M. Bhori, Y. A. Kasu, G. Bhat, and T. Marar, "Antioxidants as precision weapons in war again cancer chemotherapy induced toxicity - exploring the armoury of obscurity," Saudi Pharmaceutical Journal, vol. 26, no. 2, pp. 177-190, 2018.

[113] R. Carrasco, M. C. Ramirez, K. Nes et al., "Prevention of doxorubicin-induced cardiotoxicity by pharmacological non-hypoxic myocardial preconditioning based on docosahexaenoic acid (DHA) and carvedilol direct antioxidant effects: study protocol for a pilot, randomized, double-blind, controlled trial (CarDHA trial)," Trials, vol. 21, no. 1, article $137,2020$.

[114] G. Akolkar, Cardioprotective role of Vitamin $C$ in the mitigation of oxidative/nitrosative stress in doxorubicin-induced cardiotoxicity, A Ph.D. Thesis submitted to the Faculty of Graduate Studies, University of Manitoba, Winnipeg, Manitoba, Canada, 2017.

[115] Z. Jawa, R. M. Perez, L. Garlie et al., "Risk factors of trastuzumab-induced cardiotoxicity in breast cancer," Medicine, vol. 95, no. 44, article e5195, 2016.

[116] P. Kosalka, C. Johnson, M. Turek et al., "Effect of obesity, dyslipidemia, and diabetes on trastuzumab-related cardiotoxicity in breast cancer," Current Oncology, vol. 26, no. 3, pp. e314-e321, 2019.

[117] O. Aseyev, C. Johnson, M. Turek, A. Law, J. A. Sulpher, and S. F. Dent, "Trastuzumab-related cardiotoxicity in patients with breast cancer with comorbidities of obesity, dyslipidemia, and diabetes," Journal of Clinical Oncology, vol. 34, no. 15, p. e12503, 2016.

[118] N. Georgiadis, K. Tsarouhas, R. Rezaee et al., "What is considered cardiotoxicity of anthracyclines in animal studies Corrigendum in/10.3892/or.2020.7717," Oncology Reports, vol. 44, no. 3, pp. 798-818, 2020.

[119] G. Cai, G. Shi, S. Xue, and W. Lu, "The atherogenic index of plasma is a strong and independent predictor for coronary artery disease in the Chinese Han population," Medicine, vol. 96, no. 37, article e8058, 2017.

[120] T. Kazemi, M. Hajihosseini, M. Moossavi, M. Hemmati, and M. Ziaee, "Cardiovascular risk factors and atherogenic indices in an Iranian population: Birjand East of Iran," Clinical Medicine Insights: Cardiology, vol. 12, article 1179546818759286, 2018.

[121] E. Gómez-Álvarez, J. Verdejo, S. Ocampo, C. I. PonteNegretti, E. Ruíz, and M. M. Ríos, "The CNIC-polypill improves atherogenic dyslipidemia markers in patients at high risk or with cardiovascular disease: results from a realworld setting in Mexico," IJC Heart \& Vasculature, vol. 29, article 100545, 2020.

[122] Y. Zhan, T. Xu, and X. Tan, "Two parameters reflect lipiddriven inflammatory state in acute coronary syndrome: atherogenic index of plasma, neutrophil-lymphocyte ratio," $B M C$ cardiovascular disorders, vol. 16, no. 1, p. 96, 2016. 